\title{
Arbitration in Administrative Affairs: The Enlargement Scope of Ratione Materiae in Portugal
}

\author{
Marta Portocarrero \\ Universidade Católica Portuguesa, Catolica Research Centre for the Future of \\ Law (CEID), Faculty of Law, Portugal \\ mportocarrero@porto.ucp.pt \\ https://orcid.org/0000-0003-1199-1105
}

Received: 9. 10. 2019

Accepted: 5. 4. 2020

\section{ABSTRACT}

The purpose of this article is to address the question of arbitrability of administrative conflicts, generally and as characteristic of Portugal. Although the use of arbitration in conflicts where public entities intervene in private relationships is usually allowed, European legislatures commonly consider administrative disputes as a type of controversy excluded from arbitration. It is indeed easy to raise strong arguments against alternative dispute resolution when public administration is implicated. Nevertheless, none of the objections usually raised seems to be unbridgeable. Consequently, the article aims to critically analyse the main arguments against the power of arbitrators to rule on public conflicts. Presently, the Portuguese law allows administrative arbitration in a wide range of areas, from conflicts relating to administrative contracts to conflicts over the legality of administrative authority acts. The assessment of this regime makes it clear that the enlargement of the objective scope of administrative arbitration has to be accompanied by rules, which offer a response to the specific requirements of administrative law and a safeguard of public interest. In this sense, the analysis offers a critical review of the solutions of Portuguese law, which can be also used in comparable legal regimes of other European countries.

Keywords: alternative dispute resolution, administrative arbitration, arbitration procedure, objective arbitrability, Portugal

$J E L: K 41$

\section{Brief introduction}

This text addresses the boundaries of the arbitrability ratione materiae of conflicts in which public administration is involved, based on the analysis of the 
Portuguese legal system. We intend to approach the use of arbitration, as a conflict resolution tool usually resulting from an agreement between the parties to submit the conflict to the appreciation of private arbitrators instead of State tribunals, to relations involving Public Administration, especially when acting under administrative law.

In continental European legal systems, it is commonly accepted that administrative disputes constitute a type of controversy generally excluded from arbitration. The French Civil Code, for instance, prohibits public entities to resort to arbitration (article 206). ${ }^{1}$ Nevertheless, a total denial of the possibility of arbitrating conflicts in which public entities are involved is not a common option of European legislators, who usually choose to consider this option in a limited number of situations only. In particular, in conflicts where public entities intervene in private relationships and also as regards international and contractual relationships (Hanotiou, 2010, p. XIV; Graaf et al., 2014, p. 590-591).

The reasons for considering the arbitration path in administrative disputes are common to other forms of arbitration: the need to speed up the settlement of disputes and to ease the workload of state courts (Alfonso, 2008, p. 12; Patrikios, 1997, p. 57) ; the necessity of expertise and flexibility of procedure; and the wish for more efficiency. Furthermore, the idea of a dialogue-based relationship between public administration and individuals seems to favour alternative dispute resolution (Benvenuti, 1996, p. 27-76; Trayter, 1997, p. 76).

However, the power of private arbitrators to rule on public conflicts, that is to say, conflicts arising in the context of authority-based legal relationships, is quite controversial and normally considered "off-limits" in what regards the possibility of an arbitral appreciation.

Three main reasons are always invoked against arbitration in these matters. One can say that (1) state courts would be diminished if public entities were to substitute them for a form of private justice (Renders and Bombois, 2010, p. 54; Domenichelli, 1999, p. 45), (which can be even more contradictory in judicial systems of administrative litigation). Additionally, (2) state courts could be said to have the monopoly to judge public administration (the judgement of public administration is reserved to state jurisdiction) (Montalvo et al., 2004, p. 63; Bolado, 2010, p. 355; Nabais, 2010, p. 86). And, (3) one can argue that public power is a non-disposable power and cannot, therefore, be handed over to private judges (Trayter, 1997, p. 85; Moreno, 1998, p. 74). In short, it is legitimate to distrust arbitration in this type of conflicts and it is very easy to raise strong arguments against dispute resolution by means of arbitration when public administration is implicated (Greco, 1999, p. 167).

Still, none of the arguments mentioned above seem to be unbridgeable, depending, first of all, upon constitutional options. If the Constitution reserves the judgement of conflicts resulting from administrative activities to State

1 A rule which, nowadays, knows some exceptions, namely a law approved in 1986 which allows the State and local authorities to insert an arbitration clause in contracts celebrated with foreign entities regarding projects of national interest (see Delvolvé, 2010, p. 195; Ducarouge, 1996, p. 88). 
tribunals, as the Spanish Constitution of 1978 (article 106 (1)) and the Belgium Constitution (article 160) (Tornos, 2010, p. 202; Renders and Bombois, 2010, p. 94) seem to do, we clearly stand before an unbridgeable obstacle to arbitration of administrative conflicts. Otherwise, the remaining objections referred above are bridgeable. In this sense, the text analyses the current Portuguese legal regime (some may say a very avant-garde one), one of the systems which evolved the most in administrative arbitration in the context of European legal regimes, opening a wide range of administrative conflict situations to arbitration and, consequently, trying to solve the apparent conflict between arbitration and public law. Both the legislative evolution of that system and the discussions at doctrinal level reflect the initial objections to the extension of administrative arbitration. Rather than focusing on the admissibility of this extension, though, the truth is that presently the discussion is centred in the rules of the respective regime, in order to safeguard the respect for the fundamental principles of public law.

We therefore consider that the analysis of the evolution of administrative arbitration in Portugal presents itself as an interesting case study for an eventual replication of the regime in other systems.

This evolution was only possible in Portugal because of the existence of a constitutional position that was not contrary to administrative arbitration, and this is where we need to begin, followed by the appraisal of the scope of application of the referred institute.

\section{Methodology}

The text intends to address the delimitation of the arbitration scope in administrative legal relations by looking at the way in which the Portuguese system widened arbitration's field of application in that matter.

In this view, the matter will be approached from a strictly normative perspective, analysing the legitimacy of the solutions established in that system in the light of the fundamentals of public law.

Over the last years, normative evolution of arbitration within that framework has tried to respond to the main doctrinal objections to the way in which the determination of the arbitrability of administrative matters took place for a long period of time. The normative analysis is therefore accompanied by an appreciation of both the main impediments highlighted by authors and the solutions proposed, with the conclusion that the Portuguese case presents itself as a model capable of identifying the obstacles to the widening of arbitration in the context of public law.

On the other hand, there is no existing base for the collection of general data on arbitral decisions, since the provision of the Code of Procedure of Administrative Tribunals (article 185. ${ }^{\circ}$-B) that imposes the publication of the arbitral awards is yet to be concretized. However, it is true that some institutionalized centres have a transparency policy that allows the collection of some infor- 
mation and based on these data we will make a short empirical balance of administrative arbitration in Portugal.

\section{Results}

Based on both the analysis of the Portuguese system and the arguments that sustained the enlargement of administrative matters subject to arbitration, we believe that, in systems where judicial control of administrative activity is not reserved to State courts, arbitration of administrative matters is, as a rule, admissible. If arbitration is not seen as an institute of contractual nature and its jurisdictional nature is accepted, what needs to be confirmed is whether the Constitution of each State limits private jurisdictional activity. Otherwise, it is for the legislator to determine the range of matters to be appreciated by arbitral tribunals and to find a coherent regime that does not need to be submitted to the criterion of the disposability of the legal relationship. The advantages of the arbitration path in administrative disputes are common to other forms of arbitration, specially the ability to speed up the resolution of conflicts and to ease the workload of State courts and to provide expertise.

On the other hand, notwithstanding the favourable position towards administrative arbitration and the defence of the inexistence of absolute limits to the arbitration of public conflicts, the truth is that the widening of administrative matters' arbitrability performed by the Portuguese system has revealed that the common regime of voluntary arbitration cannot be applied blindly and that some adaptations must be foreseen to give a response to the specific requirements of administrative law and the safeguard of public interest. It is clear that the features of the relations between individuals and public entities can bring additional difficulties to the use of arbitration.

\section{Discussion}

\subsection{The Portuguese constitutional position regarding arbitration: the inexistence of a state jurisdiction monopoly in the judgement of public administration}

One might safely say that the Portuguese Constitution of 1976 holds a very favourable position regarding arbitration (Miranda and Medeiros, 2007, p. 17).

In the Portuguese Constitution, since its first revision approved in 1982, arbitration is expressly qualified as a type of jurisdiction and arbitral tribunals as a kind of court. ${ }^{2}$

2 Thereby clarifying any doubts on the legal nature (contractual or jurisdictional) of arbitral tribunals' activity - in this sense, see various decisions of the Portuguese Constitutional Court, for instance Decision 311/2008, P 753/07 and Decision 230/2013, P 279/2013, available at www.tribunalconstitucional.pt. 
Insofar as no rule can be found in the constitutional text nor in its preparatory work which prevents administrative arbitration, arbitral tribunals can also be an alternative to administrative courts (not only to civil courts) and, in this sense, an arbitral tribunal can conduct the judicial review of administrative activity. In fact, the Portuguese Constitution does not reserve the control of administrative activity to state jurisdiction, and therefore it is difficult to maintain the existence of a state monopoly in the judgement of administrative disputes. Reserving the appreciation of administrative conflicts to administrative courts is considered to aim solely at distributing matters between civil courts and State administrative courts. Therefore, it is common ground that administrative arbitration is constitutionally accepted and that public entities may agree on submitting conflicts in which they are involved to arbitration, thereby putting aside one of the main objections to administrative arbitration.

Therefore, the key question is now the determination of the types of conflicts to be subjected to the judgement of arbitrators. Over the last years, there has been a considerable increase in the types of conflicts that may be subjected to arbitration.

\subsection{The objective arbitrability of administrative disputes in the Portuguese regime}

\subsubsection{Brief historical background of the legal solutions prior to 2002 and critical review of their cornerstones: the limit of legal relations' disposability}

In the Portuguese legal system, arbitrators were traditionally limited as regards ruling on particular kinds of administrative claims.

The first Portuguese Voluntary Arbitration Law (LAV) applying to civil conflicts did not establish which administrative disputes could be solved by means of arbitration $^{3}$ and, before the entry into force of the Administrative and Tax Courts Statute of 1984 (ETAF - Decree-Law 129/84, of 27 April), there was also no general administrative rule regarding administrative arbitration. However, some special rules provided for arbitration, namely in what respects the regulation of some types of contracts (v.g. Decree-Law 48 871, of 19 February 1969). Moreover, dominant jurisprudence and legal scholarship considered the inclusion of arbitration clauses in administrative contracts, in general, rightful (Correia, 1995, pp. 231-236), in line with a general tendency among European systems (Moreno, 1998, p. 84).

In 1984, the ETAF validated arbitration over claims respecting public liability and administrative contracts (article 2(2)). The reason underlying this option was that, in those matters, public entities could settle and, consequently, their rights could be qualified as disposable rights, and that was the criterion

3 Article 1 (4) of Law 31/86, of 29 August, determined that "the State and other legal persons in public law may enter into arbitration agreements, if authorized by special law or if the object of these disputes are related to private law relationships". 
upheld by several authors and foreseen in arbitration law for determining the issues subject to arbitration (Caetano, 2010, p. 1285).

Yet, it was not allowed to submit matters related to public authority, to administrative acts, to arbitration. The main argument against the arbitrability of these issues was the non-disposability of public power (Correia, 1995, p. 234), as supported by several authors (Delvolvé, 2010, p. 202; Jarosson, 1997, p. 20; Caetano, 2010, p. 1285). When a public entity adopts an administrative act, it is exercising a power legally bound and therefore not submissible to arbitration (Graaf et al., 2014, p. 591).

In our opinion, this does not seem to be an undisputable argument, though.

The criterion of the disposability of the relationship cannot be applied to administrative relations in the same way that it is applied to private relations. Public entities are always governed in their action by the principle of legality, not only in their exercise of authority powers. In this sense, even when they enter into a contract, both the law and public interest limit public entities. Moreover, nowadays, in the Portuguese legal system, an administrative act can be replaced by an agreement between the public authority and the private entity. So, authority acts and administrative agreements are, to a certain degree, interchangeable instruments of public action (Gonçalves, 2013, pp. 790-791).

Also, the fact that, in the Portuguese system, it was admissible for an arbitral tribunal to incidentally appreciate the validity of administrative acts in matters related to contracts and public liability (for instance when an administration's harmful action stems from the adoption of an administrative act) reveals the incoherence of the regulatory solution as established at the time.

Furthermore, establishing an association between the relationships upon which public entities can settle and conflicts that can be considered by an arbitral tribunal is not, in our opinion, the right way to go. The object of a settlement agreement is the disputed situation itself and, therefore, when public entities are involved, the administrative legal capacity to undertake legal obligations or renounce to legal positions must be scrutinized. On the other hand, when referring a conflict to arbitration, the parties request a third party to determine the law applicable to the contested situation. Consequently, the object of an arbitration agreement is the waiving of judgment by a state court and not the material legal situation (Renders and Bombois, 2010, p. 74; Portocarrero, 2015, pp. 304-305).

This is why we have to consider that a settlement agreement and an arbitration agreement are not comparable, and that the former should not be used to assess the validity of the latter.

In addition, and denying the contractual nature of arbitrators' activity, we can state that, as long as arbitrators are limited to ruling according solely to the law, public entities will not hand over their power to arbitrators - they will simply ask them to apply the law to the particular case, as a state court would do. Consequently, arbitrators will play a role similar to state judges. 
In sum, the threshold of the disposable/non-disposable relationships mentioned above, usually used as an argument to exclude arbitration from public authority-based relations, is not acceptable as a criterion for determining the matters to be subjected to arbitrational appreciation.

\subsubsection{Portuguese current legal regime of administrative arbitration scope ratione materiae}

The truth is that, nowadays, Portuguese law allows administrative arbitration in a wide range of situations.

According to article 180 of the Code of Procedure of Administrative Tribunals (CPTA - Law 15/2002, of 22 February), arbitration may be used in cases related to non-contractual public liability and contracts (article 180 (1) a) and b)), but it is also possible to submit to private arbitrators the appreciation of the legality of administrative acts (article 180 (1) c)). Let us analyse each of these matters.

\subsubsection{Arbitration over the validity of administrative acts}

This legal solution that allows the arbitrational appreciation of administrative acts is the result of a process that began in 2002, when the CPTA was approved. The original wording of article 180 had some positives and negatives. The first ones included the provision for the openness of the arbitration path for the assessment of administrative acts relating to contract performance. Whereas the differentiation between acts performed by the co-contracting public entity that assumed the nature of administrative authority acts and other declarations was not clear, the solution of "article 180 (1) a) prevented the uncertainty regarding the distinction from resulting in uncertainty regarding the possible openness of the arbitration route even when there was an arbitration clause relating to the performance of the contract" ${ }^{4}$

However, concerning the possibility of proceedings before an arbitral tribunal to appreciate the validity of an administrative act, article 180 (1) c) did not provide a straightforward solution. Its original wording laid down the arbitration option with respect to acts that could be "revoked other than on grounds of their invalidity". This text was anything but clear. Seemingly, the criterion underlying the rule was once again the right to dispose of the relationship. Disposability resulted, in this case, from the discretionary power inherent to the act issued (Caupers, 1999, pp. 8-9; Leitão, 2002, p. 401; Freitas, 2007, p. 364; Otero, 2009, pp. 88-89), a thesis supported by foreign legal doctrine as well (Moreno, 1998, p. 102, pp. 109-111; Domenichelli, 1998, p. 246). If the administrative body was able to revoke the act based on its merit or convenience, that act was, to some extent, in the administration's disposability.

4 R. Medeiros, and M. Portocarrero, Administrative Arbitration, in Alexandra Correia, André Fonseca, et. al. International Arbitration in Portugal, about to be published. In some legal systems where it is possible to submit to arbitration conflicts regarding administrative contracts, scholars argue that the actes détachables theory should not be an obstacle to arbitration ruling on the subjective effects of those acts (contractual or pre-contractual liability for instance) - see D. Renders and T. Bombois, 2010, p. 68. 
Many questions emerged from this text, which is why we need to critically analyse it. The main issue pertains to the nature of the discretionary power. When the legislator leaves to the administration's discretion the search for the best solution in a particular case, it does not allow the public entity to delegate its discretionary power to arbitrators. Discretionary power belongs solely to administrative entities. Therefore, the law should exclude arbitrators from examining the discretion of administrative acts, as supported by some authors.

In line with this view, Decree-Law 10/2011, of 20 January, came into force, regulating tax arbitration. This new law expressly allowed arbitrators to rule on conflicts involving authority powers for the first time, enabling arbitration over the legality of administrative acts. ${ }^{5}$ A new paradigm was established (Almeida, 2017, p. 519).

Following this precedent, in 2015, a legislative amendment to the CPTA was passed. ${ }^{6}$ This revision provided the possibility of challenging an administrative act in an arbitral tribunal, unless otherwise specified by law (article 180 (1) c)).

This was clearly an innovative legal solution. In this sense, an arbitral tribunal can quash an administrative act unless the legislator decides otherwise. Presently, there is no expressed legislative limit yet. In our view, though, in accordance with the principle of effective judicial protection, arbitral tribunals should not be responsible for appreciating all acts where it is impossible to gather all interested parties' agreement as regards the exemption of the appreciation by the State court, namely because these acts interfere with public interests related to the community in general.

\subsubsection{Arbitration related to contracts and public procurement}

As we have already seen, article 180 (1) a)) enables the concomitant appreciation of an administrative contract and the administrative acts taken, for instance, in the context of this contract performance. This means that, apart from the traditional judicial requests for the appreciation of an administrative contract's validity, interpretation and performance, it is also possible to, nowadays, ask arbitrators to appreciate "Declarations of the public contracting party on the performance of the contract that result in: a) Orders, directives or instructions in the exercise of the powers of management and supervision; b) Unilateral modification of clauses relating to the content and method of performing the provisions set out in the contract due to reasons of public interest; c) Application of the sanctions set out for non-performance of the contract; d) Unilateral termination of the contract; e) Assignment of the co-contracting party's position in the contract to a third party' (Article 307(2) of the Code of Public Contracts (CCP) - the so-called contractual administrative acts).

\footnotetext{
5 However, this possibility was limited to a specific institutionalized arbitration centre - the Administrative Arbitration Centre (CAAD) - article 4 (2) Decree-Law 10/2011, of 20 January.

6 Decree-Law 214-G/2015, 2 October.
} 
An arbitral tribunal may, thus, annul (or declare void) an administrative act performed in the context of a contractual relationship and appreciate the validity, the interpretation and the performance of the contract.

Also as regards issues related to public procurement, article 180 (3) of the CPTA provides the possibility to refer claims regarding administrative acts taken in the context of the formation of public contracts to arbitration.

In this sense, article 180 (3) establishes that challenging an administrative act related to the formation of contracts may be the object of arbitration under the terms of the Code of Public Contracts (Decree-Law 18/2008, of 29 Januагу). The co-contracting public entity may provide for arbitration in the tender programme. Article 180 (3) also requires the provision to foresee procedural rules in compliance with the urgency required for the formation of certain types of contracts, such as public works contracts, public works or public service concessions, acquisition or leasing of movable goods, and acquisition of services. The reason underlying the legal regime is obvious: these arbitration proceedings must comply with the requirement of urgency of the Directive of review procedures in the award of public contracts (Directive 2007/66/EC of the European Parliament and of the Council).

However, not all issues regarding public procurement can be solved by arbitrators. Article 180 does not allow administrative arbitral tribunals to appreciate administrative regulations. Therefore, disputes regarding tender documents cannot be allocated to arbitration.

\subsubsection{Disputes related to public liability}

Article 180 (1) b) of the CPTA establishes that it is possible to constitute an arbitral tribunal to appreciate conflicts related to non-contractual liability in the context of administrative relationships. Being an alternative to administrative courts, administrative arbitration may concern disputes involving the liability of public entities and private persons if the harmful act or omission has been adopted or overlooked in the use of a public power.

Nevertheless, the arbitration path cannot be adopted when liability results from the exercise of political, legislative or jurisdictional functions (article 185 (1)).

\subsection{The need to adapt traditional arbitration rules}

This widening of administrative matters' arbitrability performed by the Portuguese system has revealed that some adaptations to the common regime of voluntary arbitration must be foreseen to respond to the specific requirements of administrative law and the safeguard of public interest.

In this sense, the CPTA has set out some specific rules to be applied in administrative arbitration. ${ }^{7}$

7 Recently, a proposal has been presented for an Administrative Arbitration Law - see Ana Celeste Carvalho, et. al., 2019. 


\subsubsection{The arbitration agreement}

As a rule, arbitration has its origins in a contract and, therefore, the arbitration agreement only binds the parties involved - opposing parties must agree on settling the dispute through arbitration. Taking into account the fact that very often an administrative decision affects several subjects in different ways, Article 180 (2) of the CPTA requires the acceptance of the arbitration agreement by interested counterparties in order to regularly constitute the arbitral tribunal. By opposing party, we mean any person who has an interest in the maintenance or annulment of the administrative act, a universe that can be very large in this particular case. It is indeed very difficult to define the circle of interested counterparties. Moreover, one can question if there is the need of an express acceptance of the arbitration agreement by the counterparties or if a tacit declaration is sufficient for the arbitral tribunal to be regularly constituted. Drawing a parallel with the procedural regime, it could be argued that if the affected party does not say anything when notified for the constitution of the arbitral tribunal, it may be considered that it does not object, but this solution is not legally determined.

When we consider pre-contractual proceedings, for instance, challenging a pre-contractual administrative act requires bringing the claim against the public entity but also against the other bidders.

In this respect, it is important to refer a rule recently introduced into the Code of Public Contracts (CCP). According to article 476 of the CCP, the contracting authority can decide in the procurement documents that future conflicts regarding the contract (or related administrative decisions) be necessarily submitted to an arbitration centre and, consequently, tenderers must present a declaration of acceptance of arbitration. This was the way the legislator found to guarantee the acceptance of all parties in the tender. Yet, if considered as a requirement of the proposal, its legitimacy is quite doubtful, which is why, currently, it is being discussed if this rule introduces a mandatory arbitration decided by the contracting authority or a proposal of arbitration agreement (Serrão, 2018, pp. 979-981).

\subsubsection{The need for transparency}

Another rule usually associated with the arbitration regime is the secrecy of arbitration proceedings. In this respect, it is important to stress that public activity must comply with a transparency principle. There is, therefore, the need to adapt administrative arbitration to this principle and ensure the public accountability of the Administration. ${ }^{8}$

In this regard, article 185-B of the Code of Procedure of Administrative Tribunals determines making arbitration awards public - "res judicata decisions delivered by arbitral tribunals must be published by computerised means, on a database organised by the Ministry of Justice" - and additional steps in that

8 In the French legal system, it has been already proposed to make administrative judgements public - Pierre Delvolvé, 2010, p. 218. 
direction (disclosure of all of the documents in the court's files, for instance) have been advocated. ${ }^{9}$

Recently, an amendment to the CPTA was passed (Law 118/2019, of 17 of September) that adds a new paragraph 2 of Article 185-B, which establishes that "arbitral awards can only be enforced after they have been deposited, by the arbitral tribunal, with any elements capable of identifying the person or persons to whom they relate having been duly erased, with the Ministry of Justice for computerised publication, in the terms to be defined by a decree of the member of Government responsible for the area of justice".

This norm, notwithstanding its primary aim to assure transparency, is complicated in what concerns its application because of the difficulty in guaranteeing that all arbitral decisions are communicated, particularly regarding ad-hoc arbitrations. This has led some authors to propose that the appreciation of the legality of administrative acts be limited to institutionalized arbitral tribunals.

\subsubsection{The preference for institutionalized arbitrations}

Article $476 .^{\circ}$ of the CCP, already referred above, seems to impose the use of institutionalized arbitration centres. Underlying this option is the idea that institutionalized arbitration can provide a higher degree of reliability. Granting private arbitrators the power to appreciate authority acts has to be accompanied by measures that insure similar guaranties to state courts. This is why arbitrators must offer adequate guarantees of objectivity and impartiality and provide expertise, characteristics which arbitration centres may monitor more easily. Some authors defend that the power to rule on the validity of administrative acts should only be assigned to arbitrators previously certified according to strict criteria. ${ }^{10}$

The truth is that some of the adaptations proposed above will be more easily implemented and their compliance controlled if arbitration takes place in the context of institutionalized centres, which is the reason for the justified preference for institutionalized arbitration centres.

\subsubsection{Prohibition of ruling according to equity}

A norm recently introduced in the CPTA - article 185 (2) - explicitly prohibits the recourse to equity when ruling on disputes in which the validity of administration activity is challenged: "in disputes on matters of legality, arbitrators decide strictly in line with the established law, and may not (...) judge according to equity". By referring to matters of legality, it appears to be the legislator's intention to limit this prohibition to disputes related to the validity of administrative acts, discarding the possibility of arbitrators having a say in what respects merit, discretion and administrative action, as referred above.

9 The proposal of an Administrative Arbitration Law mentioned before foresees that the arbitral proceedings are public (article 13 of the proposal).

10 The presented proposal of an Administrative Arbitration Law foresees criteria to designate administrative arbitrators that are similar to the regime established in the Tax Arbitration Law. Recently, an amendment to the CPTA was passed (Law 118/2019, of 17 September) that provides for the mentioned criteria. 
Nevertheless, one can wonder whether the same rule should be applied to all arbitral proceedings in which the legality of either an administrative act or an administrative contract is at issue.

It is worth mentioning the rule established in the Belgian legal system that provides that, when a public entity is involved, the arbitral tribunal can only rule in strict accordance with the law, unless otherwise established in particular rules. ${ }^{11}$

\subsubsection{The role of the Public Prosecutor}

In addition to its subjective function of guaranteeing citizens' rights, administrative litigation of continental systems maintains, to some extent, the objective function of controlling public legality. In this sense, in the Portuguese administrative litigation system the role of Public Prosecutor is very important. He may, for instance, propose the annulment of administrative acts, allege vices of the act different from those claimed by the author of the action and appeal autonomously against a jurisdictional decision in order to guarantee the legality of the administrative act (articles 55 (1a), 85 and 141 CPTA).

The question is whether the Public Prosecutor should have some kind of power to intervene in the arbitral process. We believe that two fundamental issues need to be pondered. Firstly, it would be difficult to defend the intervention of the Public Prosecutor in a jurisdictional process that corresponds to a private equivalent to State justice. How would it work? Secondly, we believe that, in systems like the Portuguese, where the Public Prosecutor has active procedural legitimacy to propose the annulment of administrative acts, for example, he maintains that legitimacy regardless of the arbitral agreement. It could thus be argued that, when aware of an illegality, the Public Prosecutor maintains the possibility to propose the action in State courts.

\subsubsection{Appeal}

Another very important aspect of the administrative arbitration regime concerns the possibility of parties renouncing the appeal against the arbitral decision with State tribunals, which in the case of administrative conflicts will necessarily mean that a part of the conflicts in which Public administration is involved is no more fully controlled by State tribunals. Although there may not necessarily exist a State monopoly in what respects the control of administrative activity, the possibility of State courts not having the opportunity to control arbitral awards unless the affected parties agree with it does not seem to safeguard public interest correctly.

The solution found by Portuguese law was a mitigated solution, guaranteeing that in certain circumstances there is always the possibility to appeal, particularly in case the arbitral decision is in opposition, as regards the same fundamental point of law, with a ruling issued by the Central Administrative Court"

11 Renders and Bombois, 2010, p. 143, Tanquerel and MacGregor, 2010, p. 207, advocate that an arbitration clause that allows judgment according to equity are inadmissible in the Swiss legal system. 
or "when at issue is the appreciation of a fundamental point of law which, given its social or legal relevance, is of fundamental importance, or when the action is clearly necessary for a better application of law' (article 185-A (3) CPTA). This seems a balanced solution that assures that, if arbitral awards contradict State tribunals' decisions, there is always the possibility to appeal.

\subsection{Balance of administrative arbitration in Portugal}

Making a balance of administrative arbitration in Portugal is not an easy task. As mentioned above there is no existing base for the collection of data on arbitral decisions since the provision that imposes the publication of the arbitral awards on a database organized by the Ministry of Justice is yet to be concretized.

However, some institutionalized centres, such as the Administrative Arbitration Centre (CAAD), have a transparency policy that allows the collection of some information. This centre, for instance, takes on average 4 months to issue its resolutions, which is manifestly quicker than State courts, which face an evident slowness crisis in Portugal (Silveira, 2018). ${ }^{12}$

The Centre also possesses a fees policy lower than the judicial fees in force, which allows for a cheaper justice. ${ }^{13}$

It should be noted that, in the case of tax administration, the success of tax arbitration has led to a special programme, instituted by law, of (voluntary) migration of processes from State tribunals to tax arbitration tribunals constituted within CAAD (article 11 Decree-Law 81/2018, of 15 October).

In this sense, and always taking into account the necessary adaptations referred above, administrative arbitration seems to show a positive path in the Portuguese legal system.

\section{Conclusion}

Arbitration in general presents advantages also valid for administrative arbitration, namely more flexibility, more celerity and, sometimes, fewer expenses. It can contribute to ease the workload of state courts in countries that face a slowness crisis of administrative courts.

In our opinion, and as it results from the discussion above, there are no unbridgeable obstacles in what respects the widening of administrative arbitration unless by expressed constitutional option.

Yet, it is necessary to assure the correct and due adaptation of arbitration rules to the safeguard requirements of public interest, particularly in what

12 Silveira, J. T. (2018). The CAAD Regulation establishes the maximum time limit of six months for the delivery of the arbitral award (article 25). At <https:// www.caad.pt/files/documentos/ regulamentos/CAAD_AA-Regulamento_Arbitragem_Administrativa_2020-01-23.pdf>, accessed 15 January $20 \overline{20}$.

13 See https://www.caad.pt/Files/documentos/regulamentos/CAAD_AA-Tabela_Encargos_Processuais_2019-12-12.pdf, accessed 1 January 2020. 
concerns transparency, arbitrators' impartiality and competence and prohibition of ruling according to equity in matters of legality of administrative action.

Given the difficulty of assuring the intervention of the Public Prosecutor in the arbitral process, arbitration will hardly ever control objective legality that control remains the responsibility of the State. Therefore, it is necessary to assure mechanisms to control arbitral awards, at least in cases of express conflict with State courts' decisions.

In sum, the Portuguese legislator has provided some special rules applicable to administrative arbitration in order to try to respond to the specifics that the enlargement of its scope ratione materiae seems to require. 


\section{References}

Alfonso, P. (2008). Crisis y renovación en el Derecho Público. Palestra.

Almeida, M. (2017). Manual de Processo Administrativo. Almedina.

Benvenuti (1996). L'arbitrato tra stato e societá. Foro Amministrativo, pp. 27-76.

Bolado, B. (2010). Convenios y Contratos Administrativos: transacción, arbitraje y terminación convencional del procedimiento. Aranzadi.

Caetano, M. (2010). Manual de Direito Administrativo, II. Almedina.

Carvalho, A. et al. (2019). Arbitragem Administrativa: uma proposta. Almedina, Ordem dos Advogados - Conselho Regional de Lisboa: Lisboa.

Caupers, J. (1999). A arbitragem nos litígios entre a administração pública e os particulares. Cadernos de Justiça Administrativa, 18.

Delvolvé, P. (2010). L'arbitrage en droit public français. In D. Renders et al., eds., L'arbitrage en droit public. Bruylant, p. 195.

Domenichelli. (1999). L'arbitrato nell'ambito dei lavori pubblici. In Arbitrato e Pubblica Amministrazione. Atti Convegno Milano, p. 45.

Ducarouge, F. (1996). Le juge administrative et les modes alternatifs de règlement des conflits: transaction, mediation, conciliation et arbitrage en droit public français. Revue Française Droit Administratif, 12, p. 86.

Freitas do A. (2001). Curso de Direito Administrativo, II. Almedina.

Gonçalves, P. (2013). Administração Pública e arbitragem - em especial, o princípio legal da irrecorribilidade de sentenças arbitrais. Estudos em Homenagem a António Barbosa de Melo. Almedina.

Graaf, K. J. et al. (2014). Mediation in Administrative Proceedings: a comparative perspective. In D. Dragos and B. Neamtu, eds., Alternative Dispute Resolution in European Administrative Law. Springer.

Greco, G. (1999). Modelli arbitrali e potestà amministrative. In Arbitrato e Pubblica Amministrazione. Atti del Convegno Milano.

Hanotiou, B. (2010). Préface. In D. Renders et al., eds., L'arbitrage en droit public. Bruylant.

Jarosson, C. (1997). L'arbitrage en droit publique. Actualité Juridique - Droit Administratif, p. 16.

Leitão, A. (2002). A protecção judicial dos terceiros nos contratos da Administração Pública. Almedina.

Medeiros, R. and Portocarrero, M. Administrative Arbitration. In A. Correia and A. Fonseca, International Arbitration in Portugal, to be published.

Miranda, J. and Medeiros, R. (2007). Constituição Portuguesa Anotada. Coimbra Editora.

Montalvo, R. Et al. (2004). El arbitraje ensayo de alternativa limitada al recurso contencioso-administrativo. Fundación Wellington.

Moreno, R. (1998). El arbitraje administrativo. McGraw Hill.

Nabais, C. (2010). Reflexão breve sobre a introdução da arbitragem tributária. Mais Justiça Administrativa e Fiscal, Coimbra.

Otero, P. (2009). Admissibilidade e limites da arbitragem voluntária nos contratos públicos e nos atos administrativos. II Congresso do Centro de Arbitragem da Câmara de Comércio e Indústria Portuguesa, Almedina.

Patrikios (1997). L'arbitrage en matière administrative. LGDJ. 
Portocarrero, M. (2015). Contratos sobre o exercício de poderes públicos, transação e arbitragem. UCE Porto.

Renders, D. and Bombois, T. (2010). L'arbitrage en Droit Public Belge. In D. Renders, eds., L'arbitrage en droit public. Bruylant.

Serrão, T. (2018). A arbitragem no CCP revisto. In A. Gomes et al., eds., Comentários à revisão do Código dos Contratos Públicos, pp. 979-981.

Sérvulo, C. (1995). A arbitragem voluntária no domínio dos contratos administrativos. In Estudos em memória do Professor Doutor João de Castro Mendes.

Silveira, J. T. (2018). Justiça arbitral: mitos e factos. At <www.mlgts.pt> accessed 1 January 2020.

Tanquerel, T. and MacGregor, E. (2010). L'arbitrage en Droit Public Suisse. In D. Renders et al., eds., L'arbitrage en droit public. Bruylant.

Tornos, M. (2010). El arbitraje en el derecho Administrativo en el Derecho Español. Principales problemas y últimas novedades. Mais Justiça Administrativa e Fiscal.

Trayter (1997). El arbitrage de derecho administrativo. Revista de Administracion Publica, 143, pp. 75.

Vilhena de Freitas, L. (2007). O poder de modificação unilateral do contrato administrativo pela administração. AAFDL. 